\title{
DEVELOPMENT AND EVALUATION OF A NEW GENERATION OIL PALM MOTORISED CUTTER (Cantas Evo)
}

\author{
ABDUL RAZAK JELANI*; MOHD RIZAL AHMAD*; MOHD IKMAL HAFIZI AZAMAN*; YOSRI GONO*; \\ ZAHARA MOHAMED*; SYAHMIN SUKAWAI*; ASYRAF ADUKA*; ASYRAF AZIZ*; AZWAN BAKRI*; \\ AMINULRASHID MOHAMED*; MOHAMAD BORHAN SELAMAT*; AZMAN ISMAIL*; MOHD SOLAH \\ DERAMAN*; ABD RAHIM SHUIB*; NORMAN KAMARUDIN* and KUSHAIRI, A*
}

\begin{abstract}
$M P O B$ has introduced an oil palm motorised cutter called Cantas for palms below $5 \mathrm{~m}$ harvesting height. Cantas could double up harvesting output compared to manual harvesting. However, several weaknesses viz. frequent breakdown, heavy and high vibration make it less favourable to users. This article describes the development, laboratory and field tests of the new generation Cantas called Cantas Evo. Results showed that Cantas Evo passed all the required laboratory tests. The weight and vibration of Cantas Evo are respectively 31\% and 95\% lower than the previous version of Cantas. Cantas Evo is able to reach 7 $m$ harvesting height. Field trial conducted in Kuala Muda Estate in Kedah, Malaysia revealed that the repair cost was reduced by 90\%, a saving of about RM 3000 per machine per year. With the good quality and performance, Cantas Evo is effective for palms of up to $7 m$ harvesting height. As for the economics, based on the machine cost of RM 3800 per unit, the harvesting cost comes to about RM $21.24 t^{-1}$ fresh fruit bunches (FFB), with the cost-effectiveness of RM $1.18 t^{-1}$ FFB.
\end{abstract}

Keywords: Cantas Evo, oil palm motorised cutter, harvesting tool.

Date received: 6 January 2017; Sent for revision: 9 January 2017; Received in final form: 21 August 2017; Accepted: 15 September 2017.

\section{INTRODUCTION}

Mechanisation is a pertinent approach to improve workers' productivity which is ultimately aimed at reducing workers requirement in estates. Malaysian Palm Oil Board (MPOB) has made significant breakthroughs in developing technologies of which some have been successfully commercialised such as aluminium harvesting pole (Zirafah and Hi-Reach), motorised cutter (Ckat and Cantas), mechanical loader (Grabber), fresh fruit bunches (FFB) infield transporters (Beluga and Rhyno) and loose fruit picker for loose fruits collection.

Malaysian Palm Oil Board, 6 Persiaran Institusi,

Bandar Baru Bangi, 43000 Kajang,

Selangor, Malaysia.

E-mail: razak@mpob.gov.my
The total oil palm planted area in Malaysia (as of December 2015) was about 5.64 million hectares, contributing gross income to the country of about RM 66 billion a year. It is a fact that at present the industry is really dependent on foreign labour to carry out field operations. Latest statistics shows that there are about 340283 foreign workers in this industry which accounts for about $77.8 \%$ of the total field workers in the plantation sector (MPOB, 2016). The issue has become very critical because there are cases in estates where the harvesting round has to be extended to about once in 20 to 25 days due to insufficient workers in the plantations. There are also cases where the estates have to do early replanting even when the palms are still producing good yield because they do not have workers who can harvest tall palms despite offer of high pay. A more serious problem is that more than $90 \%$ of the 
harvesting operation, the core activity in the oil palm plantation, is carried out by foreign workers. This is a very critical issue that needs to be seriously addressed. Various ways and means have to be identified to deal with the issue, and one way is through mechanisation.

\section{Oil Palm Mechanisation}

Efforts to increase workers' productivity by adopting new methods and technologies are being implemented and enhanced in the industry. There are three elements that contribute significantly to productivity of the workers, i.e. (i) tool, (ii) work system, and (iii) labour that need to be well synergised in order to achieve optimum productivity. With the right tool, effective work system and trained operators, maximum output can then be derived.

\section{Mechanised Harvesting of FFB}

Efficient harvesting can be achieved by using efficient harvesting tools and sufficient harvesters to cater to harvesting rounds of the recommended 10 to 12 days' interval. Difficulty in getting skilled harvesters has been a real issue that demands effective solutions. Manual harvesting (using a sickle or chisel) can only produce an average of $1 \mathrm{t}$ FFB per worker per day (Azman et al., 2015). Estates are now looking for more efficient harvesting tools which can increase productivity and ultimately reduce the number of workers. The harvesting productivity needs to be increased to about $4 \mathrm{t} \mathrm{FFB}$ per worker per day to reduce labour requirement significantly.

Works in developing harvesting technologies had been initiated since 1990s when a light-weight aluminium harvesting pole known as Zirafah was introduced (Abdul Halim et al., 1988; Abdul Razak et al., 1998a) to replace the cumbersome bamboo pole. Later, Abdul Razak et al. (2002) introduced the improved version (called Hi-Reach pole) which was lighter and stiffer, for better handling in tall palm harvesting. Currently, there are several brands of harvesting poles of alloy or graphite material, with two or three telescopic sections to suit the required harvesting heights.

Mohd Ramdhan and Abd Rahim (2014) reported the trial of a one-man operated mechanical harvester that involved cutting, loading and transporting the FFB from the palms to the roadside. The machine could reach palms up to $11 \mathrm{~m}$ height. It was a tracked type machine where all the deployments were hydraulically controlled. Trial conducted in several estates showed that the productivity of the machine was about $200-250$ FFB per day with the operational cost of about RM $52.44 \mathrm{t}^{-1}$ FFB (including depreciation, fuel, repair, and maintenance and labour costs). The cost of the machine was RM 220000 per unit.

\section{Oil Palm Motorised Cutter (Cantas)}

One of MPOB's technologies that has been well accepted is the oil palm motorised cutter (called Cantas) that was introduced in 2007. Cantas is suitable for harvesting FFB from palms up to $5 \mathrm{~m}$ harvesting height and was able to increase harvesting productivity by more than double. This could increase the take-home pay of the harvester and reducing the number of harvesters which is currently dominated by foreign workers. Cantas benefits the smallholder, individual harvester, contractor and estate in terms of increasing productivity and income, and reducing workers and operational costs.

Cantas is a motorised cutter specifically designed for harvesting FFB and cutting fronds. It is powered by a small petrol engine and utilises either a specially designed C-sickle or chisel as the cutting knife. MPOB is the technology owner with patents filed in Malaysia, Indonesia, Thailand, Brazil, Costa Rica and Colombia. The use of such technology will help the estates and the country to reduce foreign labour. The suitability of Cantas in relation to harvesting height is shown in Table 1. Cantas is currently manufactured by several local and international companies. Table 2 shows the average performance of Cantas against manual harvesting tool based on data collected in 21 estates (Abdul Razak et al., 2013).

TABLE 1. VERSIONS OF Cantas AND ITS SPECIFICATIONS

\begin{tabular}{|c|c|c|c|c|c|}
\hline Version & $\begin{array}{l}\text { Length } \\
\text { (m) }\end{array}$ & $\begin{array}{c}\text { Reach } \\
\text { (m) }\end{array}$ & $\begin{array}{c}\text { Cutting } \\
\text { knife }\end{array}$ & $\begin{array}{l}\text { Weight } \\
\text { (kg) }\end{array}$ & Remarks \\
\hline Ckat & 2.0 & 2.0 & Chisel & 5.0 & $\begin{array}{l}\text { Short palms } \\
\qquad(<1.5 \mathrm{~m})\end{array}$ \\
\hline Cantas3 & 2.0 & 2.0 & C-sickle & 5.0 & $1.5-2.4 \mathrm{~m}$ \\
\hline Cantas5 & 3.6 & 4.5 & C-sickle & 7.2 & $2.4-4.5 \mathrm{~m}$ \\
\hline Cantas7 & 5.0 & 7.0 & C-sickle & 7.6 & $4.5-7.0 \mathrm{~m}$ \\
\hline
\end{tabular}

\section{Problem Statement}

Cantas has been chosen as one of the project under the Malaysian Economic Transformation Programme (ETP) as a means to increase workers' productivity and reduce requirement of workers in oil palm plantation (Economic Transformation Programme Annual Report, 2012). Since its introduction, MPOB received both positive and negative feedbacks from the users. On the positive side, majority agreed that Cantas can help to speed up harvesting operation, increase harvesting productivity and reduce workers requirement. On the other hand, there are 
TABLE 2. PERFORMANCE OF Cantas vs. CONVENTIONAL HARVESTING USING POLE AND SICKLE IN ESTATES

\begin{tabular}{lccc}
\hline & Cantas & Manual & Difference \\
\hline Harvesting productivity (t FFB per day per tool) & 6.75 & 3.4 & $+3.35(+99 \%)$ \\
Workers productivity (t FFB per worker per tool) & 2.61 & 1.7 & $+0.91(+55 \%)$ \\
Labour to land ratio & $1: 32$ & $1: 20$ & $+12(+55 \%)$ \\
\hline
\end{tabular}

Note: FFB - fresh fruit bunches.

also weaknesses that need serious attention mainly on the durability and ergonomic of the machine. The weaknesses are: (i) frequent breakdown especially the cutting head, (ii) heavy, and (iii) high vibration. All these issues had caused Cantas to be less favourable, causing decline in sales since 2012. Solving these issues can apparently increase users' satisfaction hence increasing the uptake. Cause and effect analysis was made using 5W $1 \mathrm{H}$ concept which is explained in Table 3.

This article highlights the improvements that have been carried out as well as laboratory and field tests of the new generation Cantas know as Cantas Evo. These improvements were mainly aimed at increasing cost lost-effectiveness and profit to the plantations using Cantas.

\section{OBJECTIVES}

The objective of this project was to develop a new generation Cantas with the following aims:

- high quality and durable (less breakdown) with the repair cost of below RM $1.00 \mathrm{t}^{-1} \mathrm{FFB}$;

- generating vibration of below $2.5 \mathrm{~m} \mathrm{~s}^{-2}$ according to the ISO 5349 Standard; and

- having the specific weight of below $1.5 \mathrm{~kg} \mathrm{~m}^{-1}$.
Table 4 shows the gap analysis between the current standing and the target requirements.

\section{MATERIALS AND METHODS}

\section{Design}

The new design of the prototype is focussed at solving the three main issues i.e. frequent breakdown especially the cutting head, heavy weight and high vibration. The specifications of the previous version of Cantas and the design of the new version are shown in Figure 1. Four main components were involved in the improvements i.e. the cutting head, main pole, shaft guider and engine.

\section{Improvement of the Cutting Head and Vibration Reduction}

Cutting head design. The cutting head must be strong and robust to overcome the toughness of the oil palm fronds and fruit stalks and to withstand the rough handling by the harvesters (Abdul Razak et al., 1998b). It has been calculated that the revolution of the cutting mechanism (gears and connectingrod) is about one million revolutions a day which

\section{TABLE 3. 5W 1H ANALYSIS ON Cantas ISSUES}

\begin{tabular}{|c|c|}
\hline What? & $\begin{array}{l}\text { Feedback from users stated that the breakdown frequency was very high. It was also difficult to handle during } \\
\text { harvesting. These issues disrupted the harvesting operation as the workers have to stop harvesting many times } \\
\text { in a day to fix the problems and to have some rest. The improvement is very necessary to increase durability and } \\
\text { ergonomics of the machine. }\end{array}$ \\
\hline Where? & The occurrences were in the oil palm field. \\
\hline When? & It happened during harvesting and pruning activities. \\
\hline Who? & The persons involved are the harvesters, MPOB and the manufacturers of Cantas. \\
\hline Why? & $\begin{array}{l}\text { Feedback from the users have disclosed three main root causes: } \\
\text { a. Frequent breakdown, mainly the cutting head. This disrupts the smoothness of the harvesting work and } \\
\text { contributes to high repair cost. } \\
\text { b. Heavy machine which takes out workers' stamina. } \\
\text { c. High vibration of the machine affects workers' stamina and health i.e. back strain and exposes the workers to } \\
\text { hand arm vibration syndrome (HAVS). }\end{array}$ \\
\hline How much? & $\begin{array}{l}\text { The weight of the machine was between } 8.0 \text { to } 9.0 \mathrm{~kg} \text {. The repair cost was about RM } 4.03 \mathrm{t}^{-1} \mathrm{FFB} \text {. The vibration was } \\
\text { greater than } 10 \mathrm{~m} \mathrm{~s}^{-2} \text { which may trigger adverse effect to the operators. }\end{array}$ \\
\hline How? & $\begin{array}{l}\text { a. Improving the durability of cutting head - this can be done by improving the design of cutting head including } \\
\text { the selection of right material for special purposes, i.e. right material for component to stand high friction, etc. } \\
\text { b. Reducing the weight - this can be done by reducing weight of several components. }\end{array}$ \\
\hline
\end{tabular}




\begin{tabular}{lccc}
\multicolumn{3}{c}{ TABLE 4. GAP ANALYSIS } & \\
\hline Objective & Current standing & Target & $\%$ GAP \\
\hline Improve durability & Repair cost at RM4.03 t-1 FFB & $<\mathrm{RM}^{-1} \mathrm{FFB}$ & -75 \\
Reduces specific weight & $2.11 \mathrm{~kg} \mathrm{~m}^{-1}$ & $<1.5 \mathrm{~kg} \mathrm{~m}^{-1}$ & -29 \\
Reduce vibration & $10 \mathrm{~m} \mathrm{~s}^{-2}$ & $<2.5 \mathrm{~m} \mathrm{~s}^{-2}$ & -75 \\
\hline
\end{tabular}

works out to about 25 million revolutions per month. This high speed movement causes severe wear and tear on the moving parts especially on the components which rub against each other. Rough handling by the operators is another factor that can cause machine breakdown.

In the new design, several elements had been considered as follows:

- the use of 'double bearing system' on both sides of the main-gear. This would improve stability of the gear (Figure 2). A single bearing system as in the old design only provides one-sided support to the main gear which causes the gear running off during the rough harvesting operation;

- to have an in-line cutting force that generates low vibration compared to the old design (Figure 3). Offset cutting line as in the old design will generate higher vibration compared to in-line cutting action as proposed in the new design;

- to shorten the distance of stroke from $10 \mathrm{~mm}$ to $6 \mathrm{~mm}$ (Figure 4). This can lower the magnitude of vibration of the machine during operation; and

- changing of material from cast-iron into high quality metal to improve strength on certain components especially the connecting-rod.

Shaft guider. Shaft guiders are placed inside the main pole to hold and guide the shaft to rotate smoothly to transfer rotational power to the cutting head efficiently. The unbalance shaft rotation will generate high vibration that would be transferred to the pole. The previous version of Cantas employs a single-sided bearing on the shaft guider that generates high vibration during rotating.

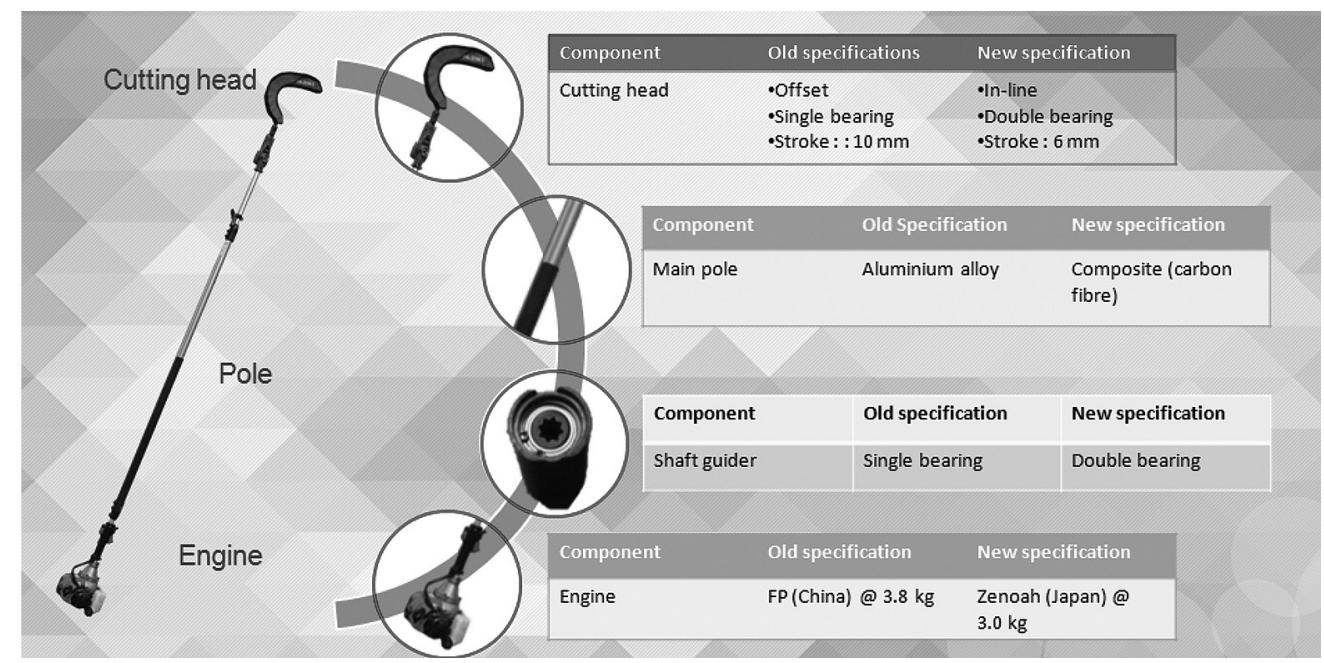

Figure 1. Proposed specification of the new design motorised cutter.

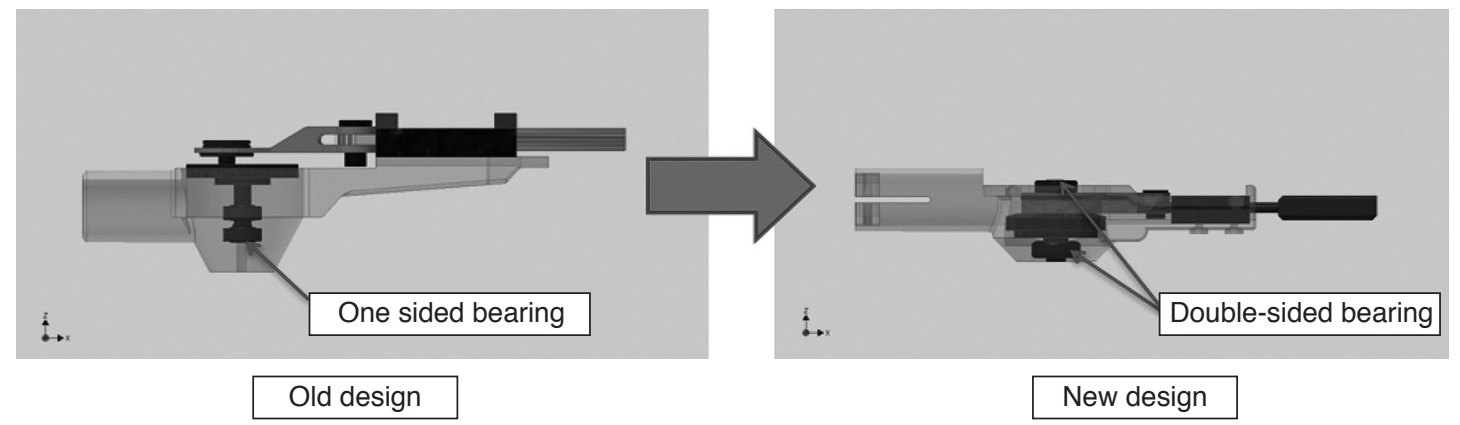

Figure 2. Previous version's design with one sided bearing (left) and new design with double-sided bearing (right). 


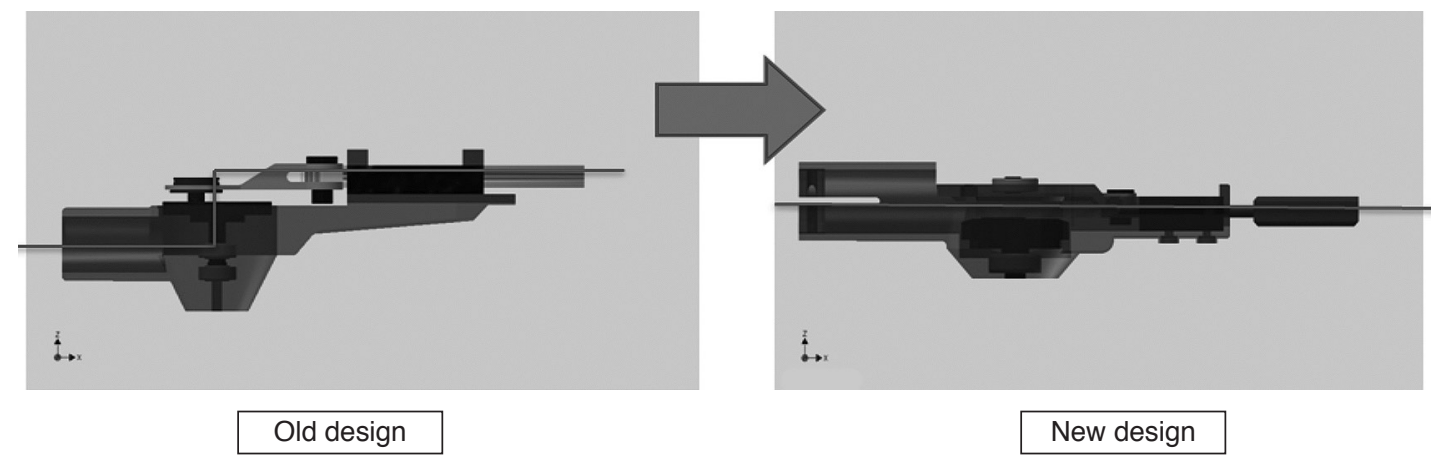

Figure 3. Previous version design with offset cutting action (left) and new design with straight cutting action (right).
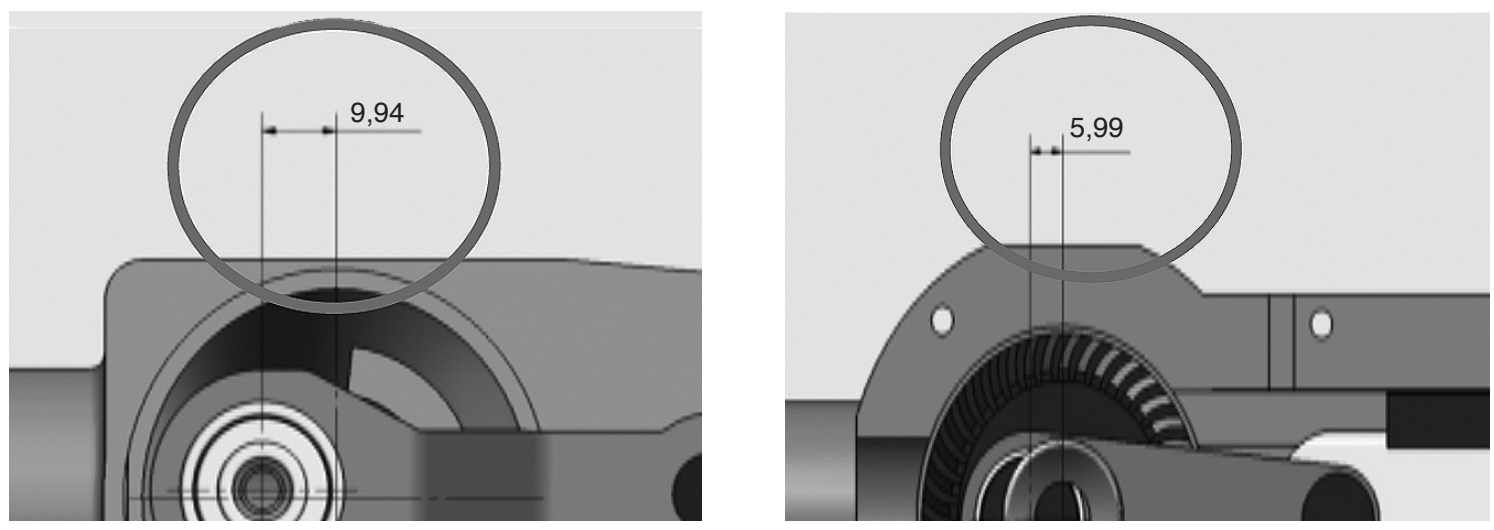

Figure 4. Displacements of old design (left) and new design (right).

In the new design, two-sided bearings are installed on the shaft guider that provides a better and steadier stability of the shaft that reduces vibration during rotating (Figure 5).

\section{Weight Reduction}

Pole design. The pole has been designed to have an oval shape as to increase surface contact area that provides a firm hand gripping during handling. The cross-section dimension is shown in Figure 6. The oval shape will increase the stiffness on the Y-axis where it is very crucial in the lifting operation to ensure the pole does not bend excessively. The ratio of Y- to X-axis is 1.14 .

In the new design, the shape remains but the material is changed into composite material (carbon fibre) which is about $20 \%$ lighter compared to aluminum alloy grade 6061 as used in the previous version.
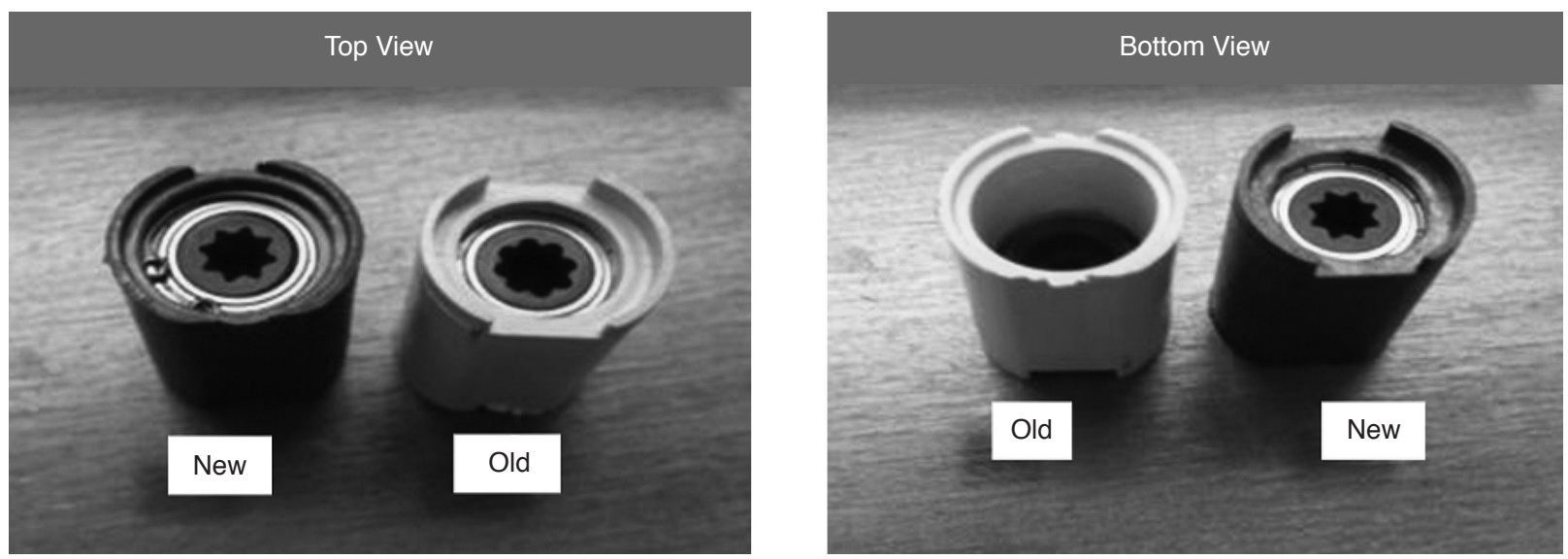

Figure 5. Old and new design of shaft guider. 


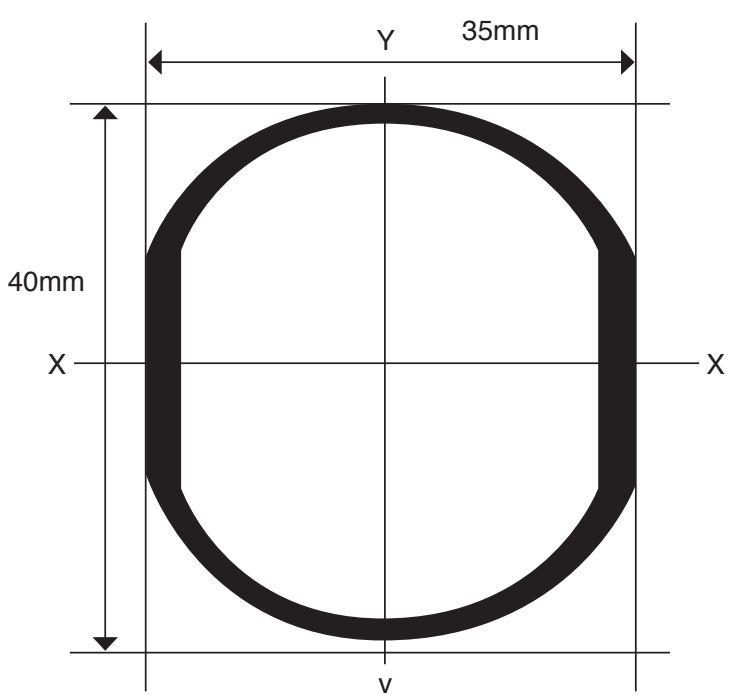

Figure 6. Cross-sectional dimension of the pole.

Engine. The previous version of Cantas was powered by a two-stroke petrol engine with the horsepower of between 1.3 to $1.5 \mathrm{hp}$. Various models of engines used were mostly imported from Germany, Japan, USA, China and Sweden. The weight of the engine ranged from 3.0 to $3.8 \mathrm{~kg}$. In the new design, however, a smaller sized engine $(1.1 \mathrm{hp})$ with a maximum rpm of 11000 is used with the weight of $3.0 \mathrm{~kg}$. With this engine, the weight is reduced by $21 \%$.

Weight and reach. The weight of Cantas is proportionate to its length. The weight gets heavier when the length is increased. There are two main constraints that play a very significant role in harvesting pole design viz. the specific weight and stiffness (Abdul Razak et al., 1998a). A material with higher Young's modulus can be approximated as rigid. A stiff material needs more force to deform compared to a soft material. Stiffness is the rigidity of an object - the extent to which it resists deformation in response to an applied force [ Equation (1) and Figure 1].

Stiffness (k) = force applied (F) /

deformation $(\Upsilon)$

For Cantas to be effective, the specific weight should remain low, but the stiffness should be set higher. High stiffness will reduce pole's deflection, where the combination of high stiffness and low weight can craft the pole to be made longer for higher harvesting reach. Several approaches have been identified to reduce weight i.e. (i) using a lighter but stronger material such as air-craft aluminium grade alloy, composite as well as polymer material, etc. (ii) reverse and re-engineering of several components such as the cutting head, pole and transmission system, and (iii) having a lighter engine but with equivalent power.

\section{Prototype of Cantas Evo}

The new prototype of the new generation Cantas is shown in Figure 8. This new version is called Cantas Evo.

\section{Testing}

Quality tests. Quality test was conducted to ensure the prototype meets the quality standard. The machine has to go through and must pass the following quality tests prior to field test, final specifications, and mass production for commercialisation.

a. Physical test. Physical test includes the machine's total length, weight and its specific weight.

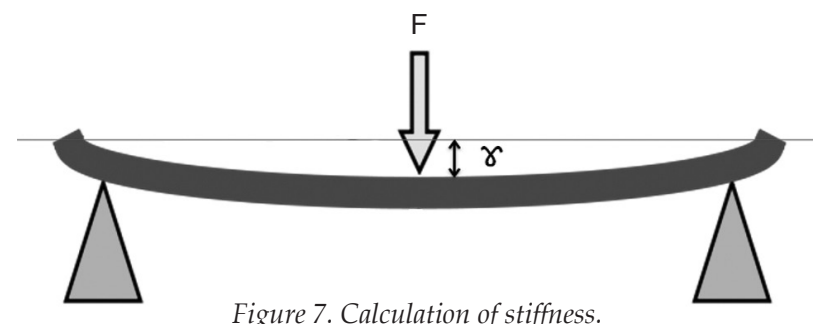

Figure 7. Calculation of stiffness.

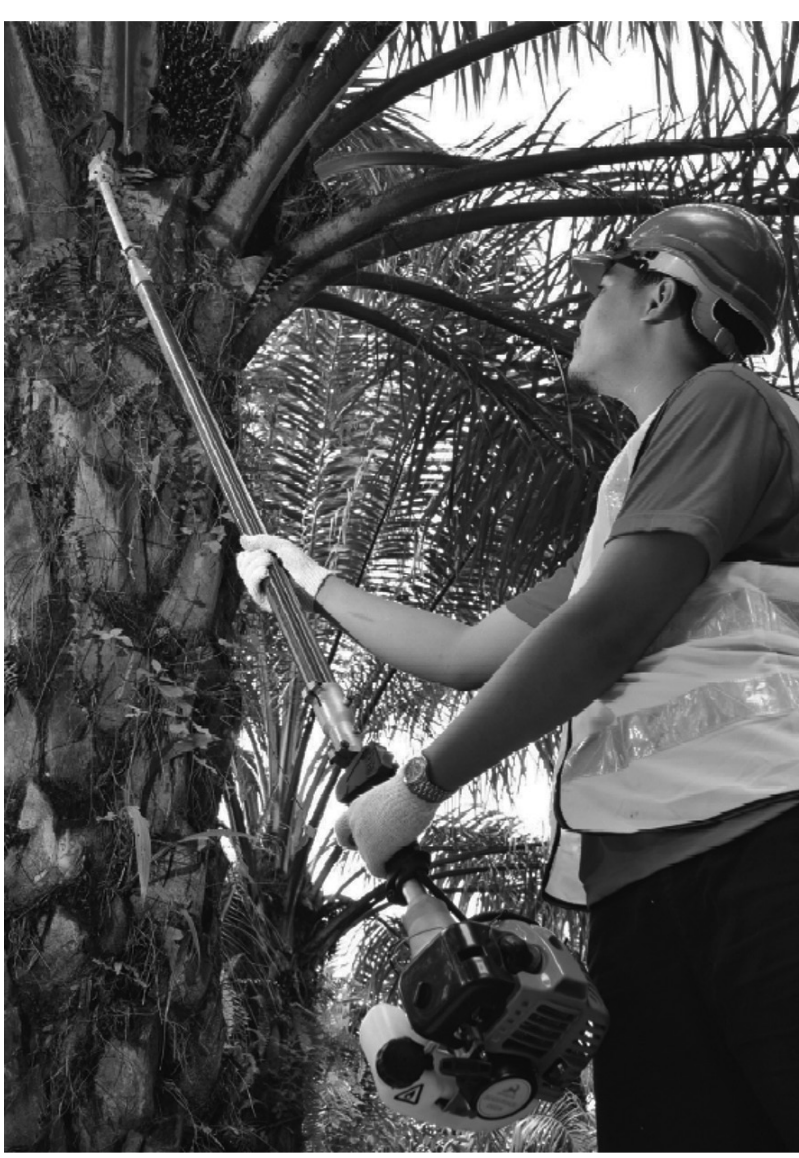

Figure 8. Prototype of the new generation Cantas (Cantas Evo). 
b. Functional test. Functional test is a test to verify whether the machine can do the job as it was designed for. The machine was tested to cut at least 10 oil palm fronds with the cutting time recorded. It must be able to cut a frond smoothly without much problem.

c. Drop test. In the drop test, the machine was dropped from different heights and angles (free fall) to see whether the machine/sample can stand the impact of falling. Two heights were set viz. 1 and $2 \mathrm{~m}$ with three different dropping angles viz. $30^{\circ}, 45$ and $60^{\circ}$.

d. Vibration test. Vibration test was carried out to measure the magnitude of vibration transferred to the hand of the user. Vibration level was measured at two points i.e. at the engine's throttle point (Point 1) and at the hand gripping point (Point 2), the point where the harvester holds the pole during harvesting (Figure 9). In the experiment, the magnitude of vibration was measured during cutting of frond. Dewesoft vibration equipment was used in this exercise.

The parameter that was investigated in the experiment was hand-arm vibration (HAV). HAV is the vibration transmitted into workers' hands and arms. This can come from use of hand-held power tools, hand guided equipment or by holding materials being worked by handfed machines.

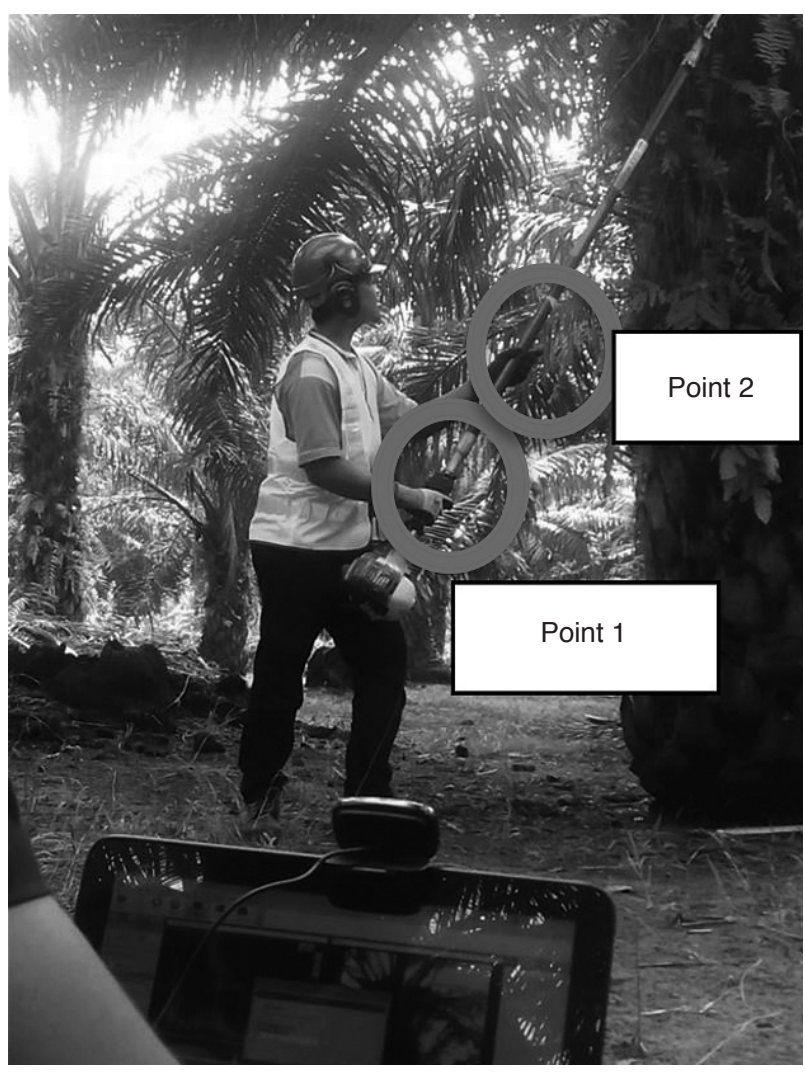

Figure 9. Vibration test during cutting operation.
The Vibration Regulations include an exposure action value (EAV) and an exposure limit value (ELV) based on a combination of the vibration at the grip point(s) on the equipment or work-piece and the time spent gripping it. The exposure action and limit values were:

- a daily EAV of $2.5 \mathrm{~m} \mathrm{~s}^{-2} \mathrm{~A}(8)$ that represents a clear risk requiring management; and

- a daily ELV of $5 \mathrm{~m} \mathrm{~s}^{-2} \mathrm{~A}(8)$ that represents a high risk above which employees should not be exposed.

EAV is a daily amount of vibration exposure above which employers are required to take action to control exposure. The greater the exposure level, the greater the risk and the more action employers will need to take to reduce the risk. For HAV the EAV is a daily exposure of 2.5 $\mathrm{m} \mathrm{s}^{-2} \mathrm{~A}(8)$.

ELV is the maximum amount of vibration an employee may be exposed to on any single day. For HAV, the ELV is a daily exposure of 5 $\mathrm{m} \mathrm{s}^{-2} \mathrm{~A}(8)$. It represents a high risk above which employees should not be exposed.

All the vibration tests followed the Control of Vibration at Work. Regulations 2005 (the Vibration Regulations) ISO 5349 (mechanical vibration - measurement and evaluation of human exposure to hand-transmitted vibration). The same procedures was used by Salihatun et al. (2014) in conducting a study on the effect of carbon fibre pole on HAV of palm fruit motorised cutter.

e. Engine performance test. Engine performance test was conducted to establish the performance curve i.e. torque and horsepower as well as other important data such as engine temperature and fuel consumption. The test was conducted using an Eddy Current Small Engine Dyno Test. In the experiment, the engine's speed variation was set from 2000 to $10000 \mathrm{rpm}$. The engine performance test was made according to ISO 1585 (for rotary piston engines and reciprocating internal combuition engines).

f. Fatigue test. Fatigue test or repetitive test is a test to examine the durability of parts or components after being exposed to repetitive movements which is similar to actual operation in the field. A controller is used to activate the machine to run within a pre-determined period. The prototype will have to work on a design load of $20 \mathrm{~kg}$. A minimum of $100 \mathrm{hr}$ test is required to investigate wear and tear incidents of parts.

\section{FIELD TEST}

The field trial is a long-term evaluation conducted in commercial plantation to assess the machine's performance and repair cost. The trial was carried 
out in Boustead Kuala Muda Estate in Baling, Kedah, Malaysia the same place where the benchmark data on previous version of Cantas was taken. As the palms have increased in height, previous version of Cantas with its maximum reach of $5 \mathrm{~m}$ was not reachable anymore. Cantas Evo that could reach $7 \mathrm{~m}$ height was thus used to continue the mechanised harvesting operation in this particular plot.

The trial was commenced in September 2014. Two samples of Cantas Evo were used in the trial, namely Sample 1 and Sample 2. The samples were tested in a 271 ha plot of 13-year old palms with the harvesting heights in the range of 7 to $8 \mathrm{~m}$.

\section{Harvesting Operation}

In the harvesting operation, two harvesting teams were formed, each team comprised of three workers i.e. one cutter using Cantas Evo, one helper (stacking fronds, cutting long stalks and arranging the cut FFB onto harvesting path) and one loose fruit collector. The payment was a sharing system where the income was equally divided among the team members. The harvested FFB were loaded and transported by a mechanical loader (mini-tractor with Grabber) to the roadside or collection points.

\section{RESULTS AND DISCUSSION}

\section{Quality Tests}

Physical test. Table 5 shows the comparison of physical properties of the new generation Cantas (Cantas Evo) and the previous version of Cantas, while Table 6 shows the physical properties of Cantas Evo.
The physical test conducted shows that the specific weight of Cantas Evo is $1.45 \mathrm{~kg} \mathrm{~m}^{-1}$ compared to $2.11 \mathrm{~kg} \mathrm{~m}^{-1}$ for previous version of Cantas, proving that Cantas Evo is lighter by $31.3 \%$.

Functional test. The results of functional test are shown in Table 7. A total of 23 fronds and 10 FFB were cut from 10 palms. It was witnessed that the machine was easy to handle, easy to perform cutting operation and the sickle was sharp.

Drop test. Table 8 shows the result of drop test from two different heights and four dropping angles. Experiment carried out proved that the machine was tough with no break, dent or malfunction on any parts of the machine.

Vibration test. The magnitude of HAV of Cantas Evo and previous version of Cantas are shown in Table 9. For Cantas Evo, the vibration level at Points 1 and 2 were 0.6 and $0.4 \mathrm{~m} \mathrm{~s}^{-2}$, respectively, while for previous version of Cantas, the vibration levels at Point 1 and 2 were 9.8 and $10.2 \mathrm{~m} \mathrm{~s}^{-2}$, respectively. Therefore, the vibration level of previous version of Cantas were above the EAV value i.e. $2.5 \mathrm{~m} \mathrm{~s}^{-2}$ [ISO 5349 (Mechanical vibration - Measurement and evaluation of human exposure to hand-transmitted vibration)]. The test has proven that Cantas Evo is safe to be used in a period of 8-hr working a day.

Engine performance test. The engine used was a Japanese made engine (Zenoah brand). The performance curve of the engine is shown in Figure 10. Test conducted showed that the maximum horsepower achieved was $1.1 \mathrm{hp}$ at $8300 \mathrm{rpm}$, while the maximum torque was $1.3 \mathrm{~N}-\mathrm{m}$ at $5700 \mathrm{rpm}$.

TABLE 5. PHYSICAL PROPERTIES COMPARISONS OF NEW GENERATION Cantas (Cantas Evo) vs. PREVIOUS VERSION OF Cantas

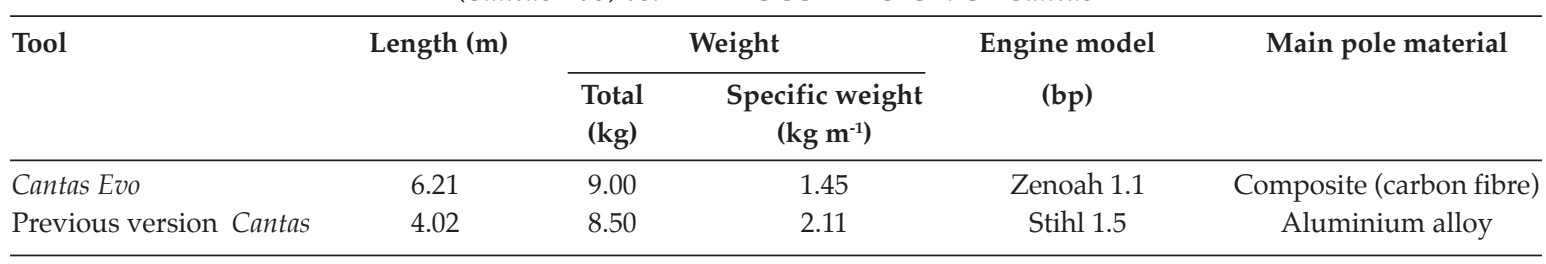

TABLE 6. SPECIFICATION OF Cantas Evo

\begin{tabular}{lccc}
\hline Description & Results & Remark & Comments \\
\hline Maximum length $(\mathrm{m})$ & 6.21 & - & - \\
Minimum length $(\mathrm{m})$ & 5.00 & - & - \\
Centre of gravity $(\mathrm{m})$ from engine & 1.40 & Short $/$ moderate $/$ far & Moderate \\
Deflection at $\operatorname{cofg}(\mathrm{cm})$ & 7.00 & Low $/$ moderate / high & Low \\
Total weight $(\mathrm{kg})$ & 9.00 & & Moderate \\
Specific weight $\left(\mathrm{kg} \mathrm{m}^{-1}\right)$ & 1.45 & Low consumption/ & Moderate \\
Fuel consumption & 0.32 litre $\mathrm{hr}^{-1}$ & moderate consumption/ & high consumption \\
(litre hr $\left.{ }^{-1}\right)$ & & &
\end{tabular}


TABLE 7. FUNCTIONAL TEST OF Cantas Evo

\begin{tabular}{ccc}
\hline Palm No. & Total fronds & Total FFB \\
\hline 1 & 2 & 1 \\
2 & 3 & 1 \\
3 & 2 & 1 \\
4 & 3 & - \\
5 & 2 & 2 \\
6 & 2 & - \\
7 & 1 & 1 \\
8 & 2 & 1 \\
9 & 4 & 2 \\
10 & 2 & 1 \\
\hline Total & 23 & 10 \\
\hline
\end{tabular}

Remark Good in handling, easy to cut and sharp

Note: FFB - fresh fruit bunches.

TABLE 8. RESULTS OF DROP TEST OF NEW GENERATION Cantas

\begin{tabular}{|c|c|c|c|}
\hline & Height & Dropping angle & Observation \\
\hline 1 & & $90^{\circ}$ & $\begin{array}{l}\text { R1 Good condition } \\
\text { R2 Good condition } \\
\text { R3 Good condition }\end{array}$ \\
\hline 2 & & $60^{\circ}$ & $\begin{array}{l}\text { R1 Good condition } \\
\text { R2 Good condition } \\
\text { R3 Good condition }\end{array}$ \\
\hline 3 & $1.00 \mathrm{~m}$ & $45^{\circ}$ & $\begin{array}{l}\text { R1 Good condition } \\
\text { R2 Good condition } \\
\text { R3 Good condition }\end{array}$ \\
\hline 4 & & $30^{\circ}$ & $\begin{array}{l}\text { R1 Good condition } \\
\text { R2 Good condition } \\
\text { R3 Good condition }\end{array}$ \\
\hline 5 & & $90^{\circ}$ & $\begin{array}{l}\text { R1 Good condition } \\
\text { R2 Good condition } \\
\text { R3 Good condition }\end{array}$ \\
\hline 6 & & $60^{\circ}$ & $\begin{array}{l}\text { R1 Good condition } \\
\text { R2 Good condition } \\
\text { R3 Good condition }\end{array}$ \\
\hline 7 & $2.00 \mathrm{~m}$ & $45^{\circ}$ & $\begin{array}{l}\text { R1 Good condition } \\
\text { R2 Good condition } \\
\text { R3 Good condition }\end{array}$ \\
\hline 8 & & $30^{\circ}$ & $\begin{array}{l}\text { R1 Good condition } \\
\text { R2 Good condition } \\
\text { R3 Good condition }\end{array}$ \\
\hline
\end{tabular}

Note: $\mathrm{R}$ - replicate.

The results of performance test were as follows:

$$
\begin{aligned}
& \mathrm{Hp}=-0.000 \mathrm{rpm}^{2}+0.04 \mathrm{rpm}+0.001 \ldots \ldots \\
& \mathrm{R}^{2}=0.938 \\
& \text { Torque }=0.000 \mathrm{rpm}^{2}+0.05 \mathrm{rpm}+0.432 \\
& \mathrm{R}^{2}=0.689
\end{aligned}
$$

Fatigue test. Test conducted showed that there was no breakdown incident within $100 \mathrm{hr}$ of fatigue test.

\begin{tabular}{lccc}
\multicolumn{3}{c}{ TABLE 9. COMPARISON OF VIBRATION LEVEL OF } \\
Cantas Evo AND PREVIOUS VERSION OF Cantas \\
\hline \\
\cline { 2 - 3 } & \multicolumn{2}{c}{ Vibration level $\left(\mathrm{m} \mathrm{s}^{-2}\right)$} & Remark \\
\cline { 2 - 3 } & Point 1 & Point 2 & \\
\hline Cantas Evo & 0.6 & 0.4 & Low - safe to use \\
Previous version Cantas & 9.8 & 10.2 & High \\
\hline
\end{tabular}

The engine temperature ranged from $80^{\circ} \mathrm{C}$ to $114^{\circ} \mathrm{C}$ which is a normal temperature as recommended, fuel consumption at 0.32 litre $\mathrm{hr}^{-1}$ with the total cycle of 5066 cycle run in 21 days or about 50 cycle hr-1. $^{-1}$

Table 10 shows the summary of results of the quality tests of Cantas Evo.

\section{FIELD EVALUATION}

Table 11 shows the comparison of results of Cantas Evo against previous version of Cantas in Boustead Kuala Muda Estate in Baling, Kedah, Malaysia. The data were taken from September 2014 to December 2015. This data was compared against data of previous version of Cantas which was taken in previous year i.e. from January to December 2013. Side by side comparison trial cannot be made as the palms were already reaching 7 to $8 \mathrm{~m}$ harvesting height which was not reachable by the previous version of Cantas. Trials conducted revealed that there is no significant difference in terms of harvesting productivity of Cantas Evo (5.38 t FFB per day) against previous version of Cantas (5.31 t FFB per day).

However there was a significant reduction on the repair cost where Cantas Evo recorded only RM $0.39 \mathrm{t}^{-1} \mathrm{FFB}$ compared to previous version of Cantas at RM $4.03 \mathrm{t}^{-1} \mathrm{FFB}$, almost $90 \%$ cost reduction. From this reduction, the estate will be able to save about RM 3000 per cantas per year. This low repair cost was made possible because Cantas Evo had fewer breakdowns i.e. only RM 594 per machine for period of September 2014 to December 2015 or RM 37 per machine per month. While for previous version of Cantas, the repair cost was RM 3407 per machine for the period January to December 2013 or RM 284 per machine per month.

Figure 11 shows the productivity of Cantas Evo for the period of October 2014 to December 2015. During peak crop i.e. from April to June 2014, the machine's productivity can reach as high as $200 \mathrm{t}$ per month or about $8 \mathrm{t}$ per day.

Table 12 shows the overall comparison of data before and after improvement was made. It can be seen that the repair cost, specific weight and vibration were reduced by $90 \%, 31 \%$ and $95 \%$, respectively. Thus, the project has met its main objectives that is to improve durability, and to reduce weight and vibration. 
Performance curve (power and torque)

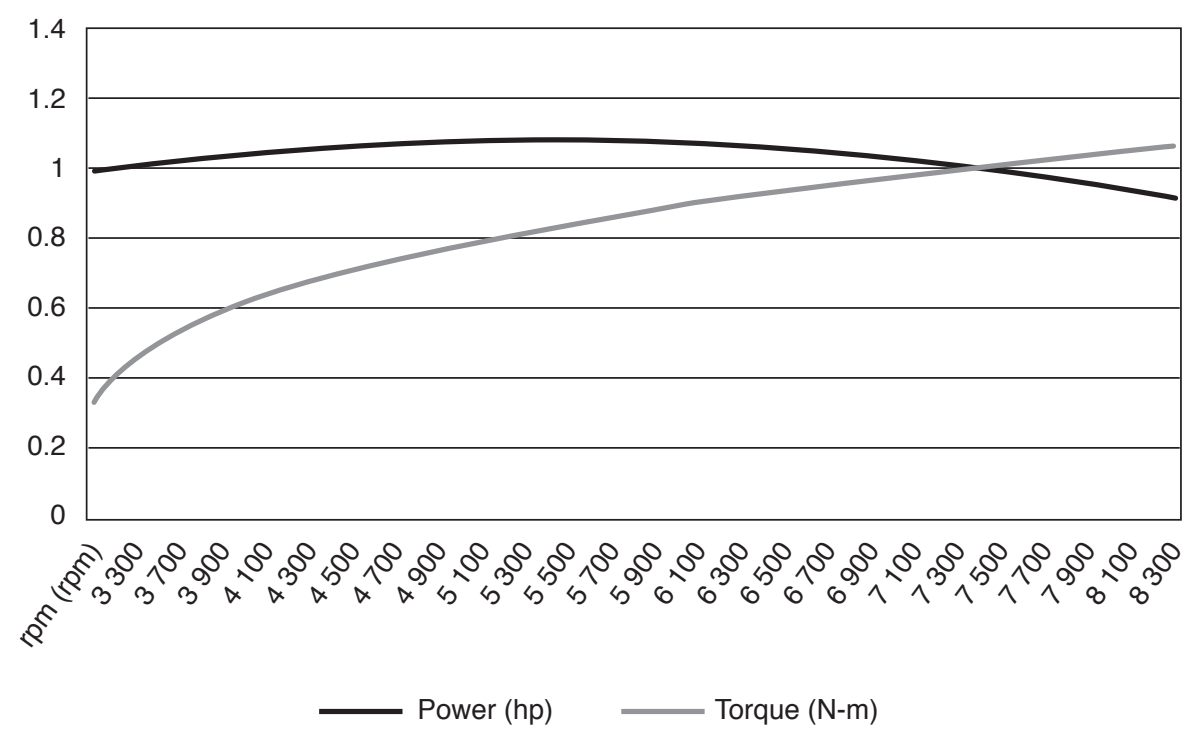

Figure 10. Performance curve of Zenoah engine (power and torque).

TABLE 10. SUMMARY OF RESULTS OF THE QUALITY TESTS OF Cantas Evo

\begin{tabular}{|c|c|c|}
\hline Type of test & Result & Remarks \\
\hline Functional test & Pass & Able to cut 10 fronds without problem. \\
\hline Drop test & Pass & $\begin{array}{l}\text { The sample was not damaged or dented after } \\
\text { being dropped from } 2 \mathrm{~m} \text { height. }\end{array}$ \\
\hline Vibration test & $\begin{array}{l}\text { At throttle: } \\
\text { At hand gripping point: }\end{array}$ & $\begin{array}{l}\text { Below the EAV limit of } 2.5 \mathrm{~m} \mathrm{~s}^{-2} \text {. } \\
\text { Engine performance test. }\end{array}$ \\
\hline Engine performance test & $\begin{array}{l}\text { Max rpm: } 10000 \\
\text { Max hp: } 1.1 \\
\text { Max torque : } 1.3 \mathrm{~N}-\mathrm{m}\end{array}$ & $\begin{array}{l}- \\
- \\
-\end{array}$ \\
\hline Engine endurance test & $\begin{array}{l}\text { Pass } \\
\text { Average temperature: } 110^{\circ} \mathrm{C} \\
\text { average fuel consumption: } 0.16 \text { litre } \mathrm{hr}^{-1}\end{array}$ & $\begin{array}{l}\text { The engine was dismantled after } 100 \mathrm{hr} \text { test } \\
\text { to see the wear and effect on the piston, } \\
\text { piston rings. No severe damage and wear and tear }\end{array}$ \\
\hline Fatigue test & Pass & $\begin{array}{l}\text { The sample was dismantled and no severe wear } \\
\text { and tear observed. }\end{array}$ \\
\hline
\end{tabular}

Note: EAV - exposure action value.

\section{ECONOMIC ANALYSIS}

\section{Cost-effectiveness}

Cost-effectiveness is measured in terms of the total FFB harvested for the period of its economic life against the price of the machine (Stanner, 1992a,b) as in the following equation:

$$
\text { Cost-effectiveness, Ec }=\frac{\text { Machine price }(\mathrm{RM})}{\text { Total FFB harvested }}
$$

$$
\begin{aligned}
\begin{array}{l}
\text { Therefore the cost-effectiveness } \\
\text { of Cantas Evo }
\end{array} & \frac{\text { RM } 3800}{\begin{array}{l}
5.38 \mathrm{t} \text { per day } \times 300 \\
\text { days } \times 2 \text { years }
\end{array}} \\
& =\mathrm{RM} 1.18 \mathrm{t}^{-1} \mathrm{FFB}
\end{aligned}
$$

The following assumptions were made:

$\begin{array}{lll}\text { Machine price, } \mathrm{M} & : & \text { RM } 3800 \\ \text { Economic life, } \mathrm{E} & : & 2 \text { years } \\ \text { Productivity, } \mathrm{P} & : & 5.38 \text { t per day } \\ \text { Labour cost, } \mathrm{L}_{\mathrm{c}} & : & \mathrm{RM} 50 \text { per day } \\ \text { Working days per year } & : & 300 \text { days }\end{array}$

\section{Payback Period}

Table 13 shows a simple cash-flow analysis with the following assumption:

$\begin{array}{lll}\text { Repair and maintenance cost } & : & \text { RM } 0.39 \mathrm{t}^{-1} \mathrm{FFB} \\ \text { Fuel cost } & : & \mathrm{RM} 0.32 \mathrm{t}^{-1} \mathrm{FFB} \\ \text { Harvesting cost } & : & \mathrm{RM} 21.24 \mathrm{t}^{-1} \mathrm{FFB}\end{array}$


TABLE 11. COMPARISON OF Cantas Evo vs. PREVIOUS VERSION OF Cantas, BOUSTEAD KUALA MUDA ESTATE, BALING, KEDAH, MALAYSIA

No. of units used

Test period

Total day

Total hour

Productivity (t FFB)

Productivity per day (per day)

Total fuel cost (RM)

Total repair cost $(\mathrm{RM})$

Total labour cost (RM)

Total running cost $(\mathrm{RM})$

Running cost per tonne FFB $\left(\mathrm{RM} \mathrm{t}^{-1}\right)$

Repair cost per tonne FFB $\left(\mathrm{RM} \mathrm{t}^{-1}\right)$
Previous version of Cantas

Sept 2014 - Dec 2015

557

1864

2998

5.38

972

1188.15

61769

63706

21.24

0.39

10

10

Jan - Dec 2013

1588

6040

8436

5.31

2791

34071

173813

211303

25.04

4.03

Note: FFB - fresh fruit bunches.

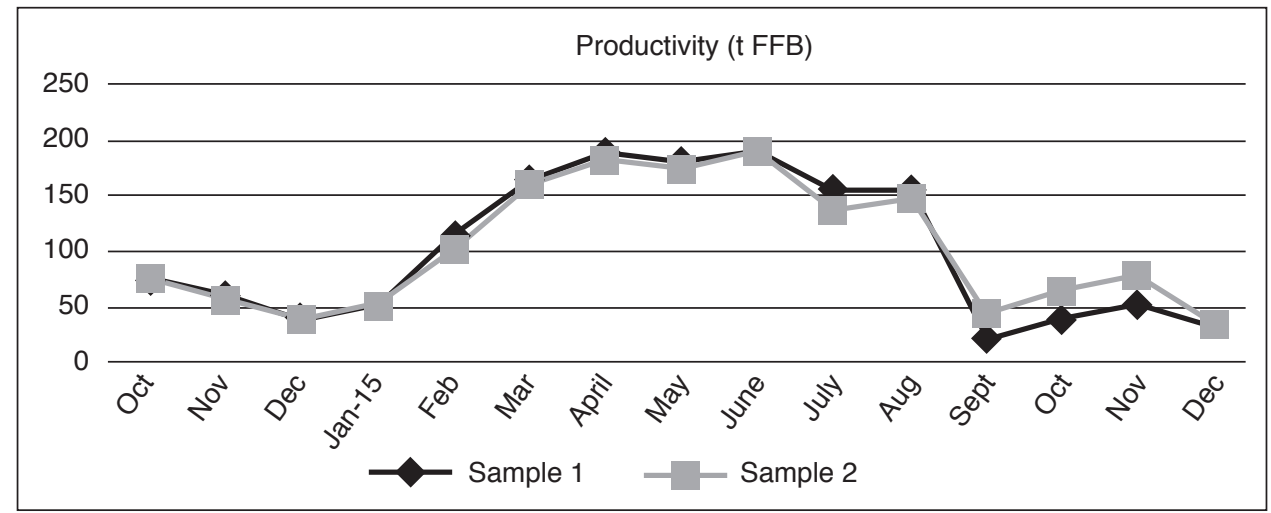

Figure 11. Monthly productivity of Cantas Evo from October 2014 to December 2015

at Boustead Kuala Muda Estate, Kedah, Malaysia.

TABLE 12. ACHIEVEMENT OF GAP ANALYSIS

\begin{tabular}{|c|c|c|c|c|c|}
\hline \multirow[b]{2}{*}{ Objective } & \multirow[b]{2}{*}{ Current standing } & \multicolumn{2}{|c|}{ Before } & \multicolumn{2}{|c|}{ After } \\
\hline & & Target & $\%$ Gap & Actual & $\%$ Achieved \\
\hline Improve durability & Repair cost at RM $4.03 \mathrm{t}^{-1} \mathrm{FFB}$ & $<\mathrm{RM} 1.00 \mathrm{t}^{-1} \mathrm{FFB}$ & -75 & 0.39 & -90 \\
\hline Reduces specific weight & $2.11 \mathrm{~kg} \mathrm{~m}^{-1}$ & $<1.5 \mathrm{~kg} \mathrm{~m}^{-1}$ & -29 & 1.45 & -31 \\
\hline Reduce vibration & $10 \mathrm{~m} \mathrm{~s}^{-2}$ & $<2.5 \mathrm{~m} \mathrm{~s}^{-2}$ & -75 & 0.5 & -95 \\
\hline
\end{tabular}

Note: GAP -

TABLE 13. SIMPLE CASH-FLOW ANALYSIS FOR THE OWNER OF Cantas Evo (per machine)

\begin{tabular}{|c|c|c|c|c|c|c|c|c|c|c|c|c|c|}
\hline Month & & 1 & 2 & 3 & 4 & 5 & 6 & 7 & 8 & 9 & 10 & 11 & 12 \\
\hline \multicolumn{14}{|l|}{ Inflow: } \\
\hline \multirow[t]{2}{*}{ FFB sales } & 8888 & & 2963 & 2963 & 2963 & 2963 & 2963 & 2963 & 2963 & 2963 & 2963 & 2963 & 2963 \\
\hline & 8888 & 0 & 2963 & 2963 & 2963 & 2963 & 2963 & 2963 & 2963 & 2963 & 2963 & 2963 & 2963 \\
\hline \multicolumn{14}{|l|}{ Inflow: } \\
\hline CAPEX & & 3000.00 & & & & & & & & & & & \\
\hline OPEX & & & 177.75 & 195.53 & 215.08 & 236.59 & 260.24 & 286.27 & 314.89 & 346.38 & 381.02 & 419.13 & 461.04 \\
\hline Total outflow & 588.35 & & 177.75 & 195.53 & 215.08 & 236.59 & 260.24 & 286.27 & 314.89 & 346.38 & 381.02 & 419.13 & 461.04 \\
\hline Profit (deficit) & 5299 & (3 000.00) & 2784.75 & 2766.98 & 2747.42 & 2725.91 & 2702.26 & 2676.23 & 2647.61 & 2616.12 & 2581.48 & 2543.37 & 2501.48 \\
\hline Cumulatitive & & & (215.25 & 2551.73 & 5299.15 & 5473.34 & 5428.17 & 5378.49 & 5323.84 & 5263.72 & 5197.59 & 5124.85 & 5044.84 \\
\hline IRR & & $75 \%$ & & & & & & & & & & & \\
\hline NPV & & RM 3529.57 & & & & & & & & & & & \\
\hline Payback period & & 3.52 & month & & & & & & & & & & \\
\hline
\end{tabular}

Note: CAPEX - capital expenditure.

OPEX - operational expenditure.

FFB - fresh fruit bunches.

IRR - internal rate by return.

NPV - net present value. 


$\begin{array}{lll}\text { Contingency cost } & : & 10 \% \\ \text { Income per month } & : & \text { RM } 2962 \\ \text { Operational cost per month } & : & \text { RM } 177.50\end{array}$

The table shows that the internal rate of return (IRR), net present value (NPV) and the payback period of Cantas Evo were 75\%, RM 3529 and 3.52 months, respectively. It means that if the average daily harvesting productivity of $5.38 \mathrm{t}, 25$ working days/month, the payback period will come to about 3.52 months.

\section{Cost per tonne FFB}

For the economic analysis, the fixed cost is the machine (Cantas Evo), while variable costs are labour, fuel and lubrication, and repair and maintenance. The operational cost per tonne FFB was calculated using a straight-line depreciation method. The details of the calculation are shown in Table 14 where the operational cost came to RM $11.10 \mathrm{t}^{-1} \mathrm{FFB}$, which is very attractive and cost-effective enough for the harvesters or estates to use Cantas Evo.

\section{CONCLUSION}

This project has met its objectives where a new generation Cantas, called Cantas Evo, was successfully designed, developed and tested. Cantas Evo with its new design of cutting head, pole, shaft guider, pole gripper and engine was found to be superior compared to the previous versions in terms of quality, weight and vibration. Cantas Evo passed all the required quality tests i.e. physical, functional, drop, vibration, fatigue and engine's performance tests. The specific weight of Cantas Evo was $1.45 \mathrm{~kg} \mathrm{~m}^{-1}$ compared to $2.11 \mathrm{~kg} \mathrm{~m}^{-1}$ for previous version of Cantas, proving that Cantas Evo is $31.3 \%$ lighter than the previous version of Cantas. While the vibration of Cantas Evo was very much below the limit which proved that it is safe to be used for $8 \mathrm{hr}$ working a day.

Long-term field trial conducted in Boustead Kuala Muda Estate in a plot of palms with $7 \mathrm{~m}$ harvesting height showed that the harvesting

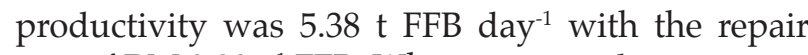
cost of RM $0.39 \mathrm{t}^{-1} \mathrm{FFB}$. When compared to previous version of Cantas, the repair cost of Cantas Evo is very much lower which in-turn could help the estate to save operational cost significantly. However, there was no significant different on harvesting productivity i.e. 5.38 t FFB per day for Cantas Evo and $5.31 \mathrm{t}$ FFB per day for previous version of Cantas.

Besides the features of high quality, lighter, low vibration and lower repair cost, the extra benefit of Cantas Evo is that it is suitable to harvest up to 7 $\mathrm{m}$ harvesting height as proven in Boustead Kuala Muda Estate.

It is accepted by operators due to its high efficiency, ergonomically designed, which offer comfort during handling, easy to operate and safe to use. Thus, as an extra benefit, it is therefore recommended that it is not only used for harvesting FFB, but can also be expanded for use as a pruning tool. With a good maintenance and care, it is envisaged that the machine would be more costeffective in the long run.

It is noted that the combination of hardware and software is very crucial to a success of any new invention. In this case, the hardware is the machine itself and software is the attitude of the operator and the system used as well as commitment from the management. A good combination of these two will be the main factor of successful mechanisation.

\section{ACKNOWLEDGEMENT}

The authors would like to express their appreciation to the Director-General of MPOB for permission to publish this article and to the manager of Boustead Kuala Muda Estate and the staff who were directly or indirectly involved in the trial by allowing MPOB to use their facilities and estate plot. Appreciation is extended to the staff of Farm Mechanisation Unit, MPOB who had given their full commitment in making the study a success. Valuable comments from fellow colleagues in improving this article are really appreciated.

TABLE 14. COST ANALYSIS OF Cantas Evo USING STRAIGHT LINE DEPRECIATION

\begin{tabular}{|c|c|c|}
\hline Description & Calculation & Cost (RM per day) \\
\hline Depreciation [price / (life span x 300 days $\mathrm{yr}^{-1}$ )] & $3800 /(2$ yr x 300 days $)$ & 6.33 \\
\hline R\&M cost @ 10\% per year of purchase price & $10 \% \times 3800 /\left(300\right.$ days $\left.\mathrm{yr}^{-1}\right)$ & 1.27 \\
\hline Lubrication cost @ 10\% of R\&M & $10 \% \times 1.27$ & 0.13 \\
\hline Total & & 59.73 \\
\hline Cost per tonne $\mathrm{FFB}=$ total cost $/$ productivity per year & RM 59.73 per day / $5.38 \mathrm{t} \mathrm{day}^{-1}$ & 11.10 \\
\hline
\end{tabular}

Note: R\&M - repair and maintenance. 


\section{REFERENCES}

ABDUL HALIM HASSAN; ABD RAHIM, $S$ and AHMAD, H (1988). An improved FFB harvesting pole - with special reference to PORIM'S aluminium pole. Paper presented at the National Oil Palm/ Palm Oil Conference - Current Developments. 11-15 October 1988, Kuala Lumpur.

ABDUL RAZAK JELANI; ABD RAHIM, $S$ and AHMAD, H (1998a). The effects of physical characteristics of aluminum pole on the harvesting productivity of tall palms. PORIM Bulletin No. 36: 13-20.

ABDUL RAZAK JELANI; DESA, A; AHMAD, H; AZMI, Y and JOHARI, J (1998b). Force and energy requirements for cutting oil palm frond. J. Oil Palm Res. Vol. 10(2): 10-24.

ABDUL RAZAK JELANI and AHMAD HITAM (2002). Design and evaluation of an improved aluminium harvesting pole (Hi-Reach) for tall palm harvesting. Oil Palm Bulletin No. 44.

ABDUL RAZAK JELANI; AHMAD, H; JOHARI, J; MALIK, N; YOSRI, G and OMAR, A (2008). Cantas $^{\mathrm{TM}}$ : A tool for the efficient for harvesting oil palm fruit bunches. J. Oil Palm Res. Vol. 20(2): 548558.

ABDUL RAZAK JELANI; RIZAL, A; IKMAL, H; SALIHATUN, M S and ABD RAHIM, S (2013). Oil palm motorised cutter (Cantas): A tool for improving workers productivity. Proc. of the PIPOC 2013 International Palm Oil Congress - Agriculture Conference. MPOB, Bangi.
AZMAN ISMAIL; SITI MASHANI, A and ZURAIHAN, S (2015). Labour productivity in the Malaysian oil palm plantation sector. Oil Palm Industry Economic J. Vol. 15 (2): 1-10.

ECONOMIC TRANSFORMATION PROGRAMME (ETP) (2012). Annual Report 2012.

HEALTH and SAFETY EXECUTIVE (2013). Hand Vibration at Work. User Guide. INDG175 (rev3) Published by the Health and Safety Executive.

KUALA MUDA HARVESTING REPORT (2013). Unpublished data. Boustead Plantations Berhad, Ladang Kuala Muda Estate, Kedah, Malaysia.

MOHD RAMDHAN KHALID and ABD RAHIM SHUIB (2014). Field evaluation of harvesting machines for tall palms. J. Oil Palm Res. Vol. 26 (2): $125-132$

MPOB (2016). Economic and Industry Development Division.

SALIHATUN, M S; ABD KADIR, M S; RAMLEE, M P; RAHIM, E A; ABDUL RAZAK, J; AHMAD, M $\mathrm{R}$ and KASRON, Z (2014). The effect carbon fiber pole on hand-arm vibration of palm fruit motorised cutter. Applied Mechanics and Materials Vol. 660: 521525.

STANNER, G H (1992a). Investigating the true cost of conventional harvesting tools. Paper presented at the Eastern Plantation Agency Bhd Seminar, Johor, June 1992.

STANNER, G H (1992b). Field trials of an improved oil palm harvesting tool. The Planters Vol. 68: 485-497. 